\title{
Value preferences in individuals with low and high self-esteem
}

\author{
Kamila Dziwota ${ }^{1}{ }_{\mathrm{ABDEF}}$, Agnieszka Dudek ${ }^{1}{ }_{\mathrm{BD}}$, Anna Szpak ${ }^{1}{ }_{\mathrm{CBD}}$, \\ Karolina Ludwikowska ${ }^{1}{ }_{\mathrm{BD}}$, Damian Kowalski ${ }^{1}{ }_{\mathrm{BD}}$, Łukasz \\ Drabarek $^{\dagger 1} \mathrm{ABD}$, Ewelina Dziwota ${ }^{2} \mathrm{DF}$, Marcin Olajossy ${ }^{2} \mathrm{DE}$ \\ 1. The John Paul II Catholic University of Lublin \\ 2. $2^{\text {nd }}$ Department of Psychiatry and Psychiatric Rehabilitation, Medical University of Lublin
}

\begin{abstract}
The basic purpose of this article is to compare how people with low and high self-esteem rated particular values. Additionally, the authors look at gender differences concerning the attitudes toward certain values.

The study involved 268 individuals aged 19-24 $(M=21.71, S D=1.54)$. The participants were surveyed using the Rosenberg SelfEsteem Scale (SES) and the Rokeach Value Survey (RVS). The results were considered significant at $\mathrm{p}<0.05$. The findings demonstrated that people with lower self-esteem had higher opinion of values like Conformity, Pleasure, and Comfortable Life as well as some Instrumental Values (Self-Control and Politeness), when compared against the individuals with higher self-esteem. On the other hand, they were found to value Courage. There were no differences concerning the way individuals with high and low self-esteem rated Social Recognition, A Sense of Accomplishment and Self-Respect.

Also, the authors noticed that men were more likely to appreciate Hedonistic and Intellectual values, while women attached greater significance to Relational values. There were no gender differences concerning the rating of Aesthetic and Subjective values.

Keywords: self-esteem, values, personality psychology

Streszczenie

Podstawowym celem artykułu jest charakterystyka porównawcza wartościowania u osób o niskiej i wysokiej samoocenie. Dodatkowo opisano różnice w wartościowaniu występujące między kobietami a mężczyznami.

Przebadano 268 osób w wieku od 19 do 24 lat $(M=21,71, S D=1,54)$ przy użyciu następujących metod: Kwestionariusz SES Rosenberga i Skala Wartości SW Rokeacha. W obliczeniach przyjęto poziom istotności p<0,05. Wyniki wskazują na to, że wartości konformistyczne (czysty, opanowany, uprzejmy, posłuszny) oraz wartości takie jak przyjemność, dostatnie życie są wyżej cenione przez osoby z niską samooceną niż przez osoby z samooceną wysoką. Osoby o wysokiej samoocenie natomiast wyżej cenią odwagę. Osoby o niskiej i wysokiej samoocenie nie różnią się w przypisywaniu ważności uznaniu społecznemu, poczuciu dokonania i poczuciu własnej godności.

Wykazano, że mężczyźni wyżej cenią wartości hedonistyczne i intelektualne, natomiast kobiety - wartości relacyjne. Nie różnią się jednak tym, jaką rangę przypisują wartościom estetycznym i podmiotowym.
\end{abstract}

Słowa kluczowe: samoocena, wartości, psychologia osobowości

\section{Introduction}

The issue of values derives from the tradition of philosophical thought, has attracted huge interest, both among authors dealing with cognitive and humanistic research there are numerous theoretical and empirical studies on this topic being published lately. [1]. The issue touches upon the most intimate human choices and the biggest dilemmas, as it concerns questions about both the meaning and purpose of an individual's life. Obviously, cultural, social and situational factors affect one's preferences for for particular values but this very article pays attention to the role of personality factors in the process of valuation. To put it simply, the impact of one's self-esteem was looked at. The aim of this study was to compare the values that subjects with both high and low self-esteem deemed as important.
A value is "an interest, taken in an object" or "respect given to a person" [2], as well as "a property or a quality of a thing which makes it useful, desirable or highly estimated" [3]. Social psychologists understand value as an extension of the concept of "attitude" [4]. "An individual value is an enduring belief that a specific mode of conduct or end-state of existence is personally or socially preferable to an opposite or converse mode of conduct or end-state of existence" [4]. The system of values is defined as "an enduring organization of beliefs concerning preferrable modes of conduct or end-states of existence along a continuum of relative importance" [5]. Value systems are a central part our individual belief systems and they are usually are characterized by high stability. Values have a universal character [4]. There is huge possibility 
that all people appreciate the same values, regardless of time and place but individuals differ when it comes to the importance that they attribute to those values. There are two groups of values: terminal, which relate to the most important goals in life and instrumental, which refer to modes of behavior and can be considered as means of achieving the terminal values.

According to Scheler [6], unlike mental or material entities that exist in reality, values exist as ideal entities. The values that have an appropriate structure and that are logically consistent and encompass all activities of an individual form a hierarchy. This hierarchy remains relatively constant throughout a lifetime [7]. Basically, values have a regulatory function. Oftentimes, they are a reflection of an individual's needs. They may form impressions of the surrounding world - both other people's behaviors and various phenomena. Furthermore, values affect individuals' decisions about life. For instance, a person that values an adventurous life is likely to seek constant stimulation and adventure. This correlation, however, is not always so clear. For instance, it may seem that athletes would highly appreciate values associated with the body or the physical sphere of life. Conversely, research has shown that these individuals place great importance on religious, moral and family values [8].

One's values affect individual self-esteem which affects one's behavior. Feather paid attention to the relationship between one's self-esteem and their values [9]. He noticed that the correlation between these variables is largely due to the social pressure put on the majority to prefer some specific values. For example, people living in culture circles that emphasize the importance of personal skills and achievement tend to perceive these sets of skills and related achievements as an important source of self-esteem. An individual's successes or failures on the way to meeting those preferred values will determine his or her self-esteem. In addition, the outcomes of these experiences can be ascribed to different degrees to factors inherent in the individual. The higher that degree, the more such experiences would affect self-esteem. Feather [9] assumes that achievement and competence are the values most closely associated with self-esteem. Self-esteem is closely linked with specific values which can be qualified as growth needs (positively correlated with high self-esteem) and deficiency needs (negatively correlated with self-esteem) [10]. For example, one of the growth needs - kindness [11] correlates with high self-esteem [12]. Probably, people with high self-esteem appreciate Politeness more than those with low self-esteem do (Hypothesis 1).

Self-esteem is a global and relatively constant evaluation of one's own abilities [13]. It builds around the "Ego" and constitutes an important source of regula- tory functions. Self-esteem is an integral part of one's concept of the self, since it determines individual's attitudes toward the information about the self and selfknowledge [14]. Self-esteem, or evaluation of oneself, is associated with concepts like self-worth and a sense of one's own efficiency and competences [13]. On the one hand, it might be related to overestimating oneself and underestimating oneself at the same time. High selfesteem is related to a positive self-image and a better frame of mind. People who have higher sense of selfesteem (as measured by the Attitude of Sympathy Index [Polish, wskaźnik nastawienia sympatii]) attach greater significance to self-respect [15]. They also have a greater tendency to demand respect for their rights and they are more likely to "take matters in their own hands". [16] Therefore, it might be expected that people with higher self-esteem would tend to attach greater importance to the value of Self-Respect (Hypothesis 2).

At the same time, low self-esteem should not be regarded as a consequence of any negative information about the self but rather a lack of positive information [13]. The projection of the self that people with a lower selfesteem have is more realistic and their evaluations tend to be more accurate. However, these individuals might easily give up even when dealing with simple tasks; they also tend to be in a poorer frame of mind and are more likely to fall into depression or engage in self-destructive behaviors. They are looking for compensation for their disadvantages instead of making their position stronger - as it is the case with individuals with a higher selfesteem. For example, people who are addicted to work (those who attach the most importance to work-related matters) highly appreciate work as a value which is a measure of both the social status and prestige [17]. Personality-related determinants of workaholism include, among others, unstable self-esteem and feelings of inferiority. Since values are associated with an individual's objectives and needs [18] it can be assumed that people with low self-esteem have a strong need for accomplishment, which translates into their valuation system (Hypothesis 3).

It can be assumed that self-esteem, to some extent, results from interpretation of difficult experiences and can be used as a prejudice against (low self-esteem) or a positive attitude to (high self-esteem) some has regarding new tasks. At the same time, it is a fully subjective judgement. Individuals with low self-esteem tend to react to any signs of criticism coming from people around them in a hugely emotional way - even with "tears" at their self-esteem [19]. Individuals with low self-esteem often set high performance standards which might be a means to increasing their self-worth, allowing them to receive recognition and enjoy others' ac- 
ceptance [17]. It can be assumed that people with low selfesteem will attach a greater significance to social recognition than people with high self-esteem (Hypothesis 4).

There are many interesting mechanisms behind one's self-esteem. If any dangers to one's Ego appear, people attempt at being positively evaluated in other contexts. [13] Furthermore, individual's efforts to make a positive self-presentation are intended to protect us from a lowered self-esteem [20]. Self-esteem is a safeguard against the fear of being lonely, useless, and abandoned [21]. High self-esteem, i.e. being aware of one's own capabilities and the effectiveness of one's actions provides an individual with a sense of being accepted and being an important member of society, allowing them to overcome the fear of alienation. To some extent, this is similar to the socio-metric theory of self-esteem [20]. According to the authors of this theory, there is a relationship between state self-esteem and trait self-esteem, on the one hand, and social rejection and anxiety, on the other. The system of self-esteem works as a sociometer - it monitors the behavior of a person and their environment, as well as detects signals of social disapproval and rejection. Upon detecting the signals of lack of acceptance, the self-esteem system notifies the individual about it giving rise to negative emotions. The person, looking to avoid them alters their behavior, so that proper relations with the environment are restored.

Self-esteem can be treated as both a trait and a condition. On the one hand, it is a relatively stable disposition, to a large extent determined by the genes [22] but on the other hand, it can be demonstrated to be subject to certain situational variability. Rosenberg [22] argues that situational fluctuations are usually short-lived and leave no lasting trace in the so-called base level of selfesteem. Interestingly, global self-esteem is more susceptible to change than specific self-esteem [22]. Selfesteem may fluctuate depending on one's mood, on how successful one's positive self-presentation has been, the feedback one gets about oneself or the degree of acceptance expressed by others. In light of the sociometric theory, trait self-esteem is a generalized sense of one's own worth in relationships with other people, which, in a sense, defines one's position in a certain group. Low self-esteem may suggest that a person has been frequently rejected by the group. It has been shown that such people are more sensitive to signals of disapproval - they are more likely to notice them than are people with high self-esteem. They are also more likely to experience embarrassment, shame and tend to avoid social situations, which lowers their social status [23]. They are familiar with negative experiences in relationships and at the same time receive little support [22], despite the fact that they are characterized by greater conformi- ty, which should let them win more sympathy. It has been demonstrated that conformists appreciate the following instrumental values: Self-Control, Politeness, Obedience, and Cleanliness [24]. These are the values which allow individuals achieve objectives related to affiliation with their group. People with low self-esteem are more conformist than people with high self-esteem [25], which is why the above-mentioned values should be more important to the former than to the latter (Hypothesis 5).

To sum up, an analysis of the literature on the relationships between self-esteem and values outlined above suggests the following: People with higher selfesteem attach greater importance than people with low self-esteem to 1) Politeness and 2) Self-Respect, and attribute lower importance to 3) A Sense of Accomplishment, 4) Social Recognition and 5) Conformity Values such as Cleanliness, Self-Control, Politeness, and Obedience.

The present study is of a correlational type.

\section{Participants}

The study involved 268 people (134 men and 134 women) aged 19-24. All participants were students of Lublin universities. They did not receive any remuneration for participating in the study. The mean age of all respondents was $M=21.71$, and standard deviation was $S D=1.54$. The mean age for women was $M=21.66, S D=1.54$. In the male group, the mean age was $M=21.76, S D=1.55$.

\section{Methods}

The study was conducted using the Rosenberg Self-Esteem Scale (SES) adapted into Polish by Dzwonkowska, Lachowicz-Tabaczek and Łaguna, and The Rokeach Value Survey (RVS) in the Polish version by Brzozowski.

SES is one of the most commonly used instruments for measuring self-esteem. It is simple and easy to use. The questionnaire consists of 10 items arranged in a table. The items are answered on a 4-point scale (from strongly agree to strongly disagree). A high score on the SES indicates high self-esteem. This instrument can be used on both adolescents and adults [22].

The Rosenberg scale has good psychometric properties. Sten norms were developed for the scale - separately for men and women.

The Rokeach Value Survey [5] is an instrument for testing the value systems of adolescents and adults. It is used for research purposes.

When developing the Survey, Rokeach came up with a theory defining personality as a system of beliefs classified into 10 sub-systems, among which there are terminal and instrumental values. The systems of these values are central to the whole system of beliefs. This testifies to their important role, as well as their regulatory function [26]. 
RVS consists of two parts, each containing 18 values in alphabetic order. The first part (TV) concerns terminal values, and the other (IV) - instrumental values. A participant's task is to arrange the values in order of their perceived importance, starting from the most important and ending with the least important. The 18 terminal and 18 instrumental values are ranked separately. The scale is designed for testing both groups and individuals.

\section{Procedure}

The participants were asked to complete both SES and RSV in a paper form. The respondents completed the scales individually, with no time constraints imposed.

The instrumental values recognized by Schwartz and Bilsky [24] as falling into the realm of restrictive conformity, i.e. Cleanliness, Self-Control, Politeness, and Obedience are referred to here as Conformity values. These researchers have shown that there are correlations between these values and conformity.

To compare gender preferences in terms of values, the investigated values were divided into groups on the basis of Brzozowski 's elementary analysis of correspondence [27]. Using semantic differential, this researcher identified several semantically close "sets" of values. Referring to Brzozowski's classification, the authors of the present article also used a similar division.

Instrumental values like Love, Self-Control, Cheerfulness, Forgiveness, Politeness, and Obedience were ascribed to the group Relational values. The instrumental values Intellect and Logic formed the group of Intellectual values. Some of the Terminal values were classified into the fol- lowing groups: Hedonistic values (A Comfortable Life, Pleasure, An Exciting Life), Subjective values (A Sense of Accomplishment, Self-Respect, Freedom, Inner Harmony) and Aesthetic values ( $A$ World of Beauty). The main point of reference for group naming was the objective that could be achieved by adhering to these specific values in life [24].

\section{Results}

The mean scores and standard deviations on the Rosenberg Self-Esteem Scale (SES)

The mean age of all participants in the Rosenberg SES was $M=5.52$ and standard deviation was $S D=1.99$. The raw scores were converted into sten points. The mean age for women was $M=5.63, S D=1.99$. In the male group, the mean age was $M=5.41, S D=2.00$ (Fig. 1).

The sten scores were broken down into low, medium and high scores, and the participants were accordingly assigned to groups with different levels of selfesteem. The number of people with low self-esteem was $N=79$, those with high self-esteem $N=94$, and those with medium self-esteem $N=93$.

In the group of people with low self-esteem, the mean score was $M=3.24, S D=0.95$. The scores ranged from 1 to 4 on a 10 -point scale.

In the high self-esteem group, the mean score was $M=7.65, S D=0.89$. The scores ranged from 7 to 10 .

The participants with scores between 5 and 6 were classified as having medium self-esteem. The mean score in this group was $M=5.39, S D=0.49$.

Figure 1. A bar graph of SES scores expressed as stens (1-10). The scores are plotted on the horizontal axis. The vertical axis shows sample size i.e. the number of participants

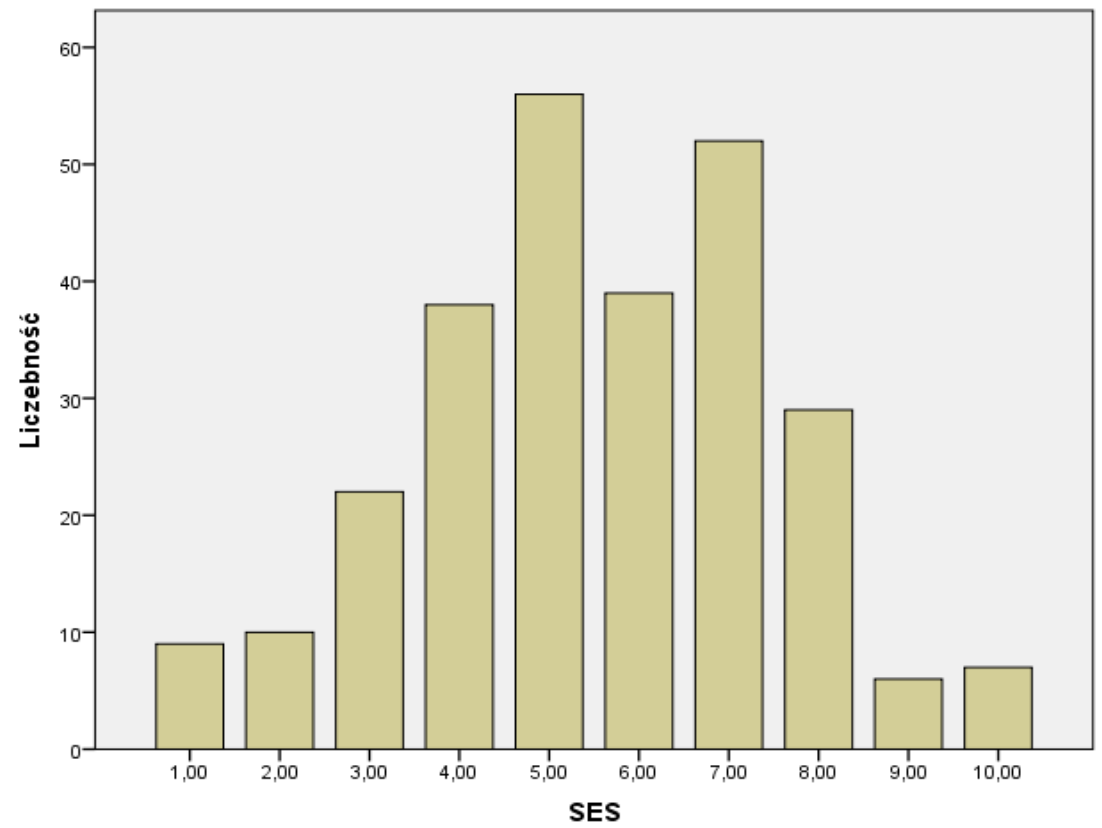




\section{Scores on the Rokeach Value Survey Scale}

After the participants completed the RVS, the ranks assigned to the individual values were averaged. In the score analysis, a lower mean meant a specific value was ranked higher. When completing the Survey, the respondents arranged the values in order of their subjective importance (to a person). A 1 stood for the highest rank (the highest importance) and an 18 for the lowest rank. Thus, a lower mean score for a particular value meant that this value was assumed to be more important to the participants than values with higher mean scores.

The mean scores for Terminal values for the whole test group are presented in Table 1.

Table 1. Scores on the Terminal Values Scale of the Rokeach Value Survey M - mean score, SD - standard deviation

\begin{tabular}{|l|c|c|}
\hline Value & M & SD \\
\hline National Security & 11.98 & 5.07 \\
\hline Family Security & 4.81 & 4.11 \\
\hline Mature Love & 5.42 & 4.44 \\
\hline A Comfortable Life & 10.21 & 4.88 \\
\hline Wisdom & 6.07 & 3.70 \\
\hline A Sense of Accomplishment & 9.99 & 4.27 \\
\hline Self-Respect & 7.00 & 3.91 \\
\hline A World at Peace & 12.51 & 4.54 \\
\hline True Friendship & 7.52 & 4.05 \\
\hline Pleasure & 11.87 & 4.05 \\
\hline Inner Harmony & 8.82 & 4.35 \\
\hline Equality & 11.51 & 4.14 \\
\hline Happiness & 7.15 & 4.38 \\
\hline A World of Beauty & 13.33 & 4.22 \\
\hline Social Recognition & 12.07 & 4.06 \\
\hline Freedom & 7.34 & 4.32 \\
\hline Salvation & 9.48 & 6.34 \\
\hline An Exciting Life & 13.36 & 4.09 \\
\hline
\end{tabular}

Mean scores on the Rokeach Scale show that the terminal values most appreciated by the participants were Family Safety, Mature Love, Wisdom, and SelfRespect. The least importance was attached to such values as National Security, A World at Peace, Pleasure, Equality, A World of Beauty, Social Recognition, and An Exciting Life.

The mean scores on the Instrumental Values Scale for the whole group of participants are presented in Table 2.

The most highly appreciated instrumental values in the investigated group of respondents were Love, Politeness, Responsibility, and Ambition. People ascribed least importance to values like Obedience, Capability, Cleanliness, and Imagination (table 2).
Table 2. Scores on the Instrumental Values Scale of the Rokeach Value Survey M - mean score, SD - standard deviation

\begin{tabular}{|l|c|c|}
\hline Value & M & SD \\
\hline Ambition & 7.49 & 4.87 \\
\hline Cleanliness & 10.87 & 4.92 \\
\hline Intellect & 9.06 & 5.06 \\
\hline Love & 5.56 & 4.89 \\
\hline Logic & 10.01 & 5.27 \\
\hline Independence & 9.29 & 5.18 \\
\hline Imagination & 10.85 & 4.64 \\
\hline Responsibility & 7.08 & 4.86 \\
\hline Courage & 9.16 & 4.59 \\
\hline Self-Control & 10.47 & 4.72 \\
\hline Broad-Mindedness & 10.27 & 4.91 \\
\hline Cheerfulness & 9.91 & 4.80 \\
\hline Helpfulness & 8.21 & 4.47 \\
\hline Obedience & 14.34 & 4.16 \\
\hline Honesty & 9.72 & 4.62 \\
\hline Politeness & 6.04 & 4.52 \\
\hline Capability & 11.38 & 4.39 \\
\hline Forgiveness & 10.89 & 4.97 \\
\hline
\end{tabular}

\section{The results of statistical analyses for each hypothesis}

The hypotheses put forward in this very study were verified using an independent samples t-test in SPSS Statistics. The calculations were performed using mean rank scores for the individual values and groups of values, and sten scores obtained by participants with high and low self-esteem. Moreover, a comparison was made between women's and men's scores within value groups. The results of the independent samples t-test were considered significant at $p<0.05$.

\section{Values and the level of self-esteem}

Initially, according to the adopted research hypotheses, the authors performed a statistical analysis of differences in value preferences between the low self-esteem and the high self-esteem group (table 3).

Statistically significant differences between the low self-esteem group and the high self-esteem group were found for Politeness and Conformity Values (table 3).

\section{Politeness vs. Self-Esteem}

The first of the hypotheses being verified concerned the relationship between high self-esteem and a higher importance of Politeness than in the low self-esteem group. The independent samples t-test showed statistically significant results ( $t=1.99, p=0.048$ ). Hence, the hypothesis was not confirmed. It was shown that people with low self-esteem valued Politeness more than those with high self-esteem. 
Table 3. The results of an independent samples t-test of values preferred by the low and the high self-esteem group

\begin{tabular}{|l|c|c|c|c|c|c|}
\hline \multirow{2}{*}{ Values } & \multicolumn{2}{|c|}{ High Self-Esteem } & \multicolumn{2}{c|}{ Low Self-Esteem } & \multicolumn{2}{c|}{ Independent samples t-test } \\
\cline { 2 - 7 } & $\mathrm{M}$ & $\mathrm{SD}$ & $\mathrm{M}$ & $\mathrm{SD}$ & $\mathrm{p}$ & $\mathrm{t}$ \\
\hline Politeness & 10.26 & 4.36 & 8.89 & 4.60 & 0.048 & -1.99 \\
\hline Self-Respect & 7.51 & 4.07 & 6.68 & 3.54 & 0.150 & 1.44 \\
\hline A Sense of Accomplishment & 9.64 & 4.38 & 9.92 & 4.25 & 0.677 & 0.41 \\
\hline Social Recognition & 12.82 & 4.30 & 11.68 & 4.20 & 0.407 & -0.83 \\
\hline Conformity Values & 47.88 & 8.96 & 43.29 & 9.87 & 0.002 & -3.20 \\
\hline
\end{tabular}

M - mean score, SD - standard deviation

Table 4. Results of an independent samples test of value preferences of female $(\mathrm{N}=134)$ and male respondents $(\mathrm{N}=134)$

\begin{tabular}{|l|c|c|c|c|c|c|}
\hline \multirow{2}{*}{ Values } & \multicolumn{2}{|c|}{ Women } & \multicolumn{3}{c|}{ Men } & \multicolumn{2}{c|}{ Independent samples t-test } \\
\cline { 2 - 7 } & $\mathrm{M}$ & $\mathrm{SD}$ & $\mathrm{M}$ & $\mathrm{SD}$ & $\mathrm{p}$ & $\mathrm{t}$ \\
\hline Relational & 59.19 & 13.28 & 62.65 & 13.04 & 0.032 & 2.15 \\
\hline Intellectual & 21.94 & 7.36 & 16.21 & 7.68 & 0.000 & -6.23 \\
\hline Subjective & 32.41 & 8.35 & 33.92 & 8.61 & 0.147 & 1.45 \\
\hline Aesthetic & 13.70 & 3.79 & 12.96 & 4.59 & 0.148 & 1.45 \\
\hline Hedonistic & 38.41 & 8.14 & 32.50 & 9.61 & 0.00 & -5.43 \\
\hline
\end{tabular}

$\mathrm{M}$ - mean, $\mathrm{SD}$ - standard deviation, $\mathrm{N}$ - sample size

Table 5. Results of an independent samples test of value preferences of respondents with high and low self-esteem

\begin{tabular}{|l|c|c|c|c|c|c|}
\hline \multirow{2}{*}{ Values } & \multicolumn{2}{|c|}{ High Self-Esteem } & \multicolumn{2}{|c|}{ Low Self-Esteem } & \multicolumn{2}{c|}{ Independent samples t-test } \\
\cline { 2 - 7 } & $\mathrm{M}$ & $\mathrm{SD}$ & $\mathrm{M}$ & $\mathrm{SD}$ & $\mathrm{p}$ & $\mathrm{t}$ \\
\hline Self-Control & 1.39 & 4.45 & 9.54 & 4.54 & 0.011 & -2.57 \\
\hline Courage & 8.32 & 4.28 & 10.24 & 4.80 & 0.032 & -2.16 \\
\hline Pleasure & 2.72 & 3.46 & 11.40 & 4.38 & 0.008 & -2.68 \\
\hline A Comfortable Life & 10.95 & 4.66 & 9.12 & 4.64 & 0.007 & 2.73 \\
\hline
\end{tabular}

$\mathrm{M}$ - mean, SD - standard deviation, $\mathrm{N}$ - sample size

\section{Self-Respect vs. Self-Esteem}

The results also failed to confirm the hypothesis that lower self-esteem was associated with assigning a higher rank to Self-Respect ( $t=1.44, p=0.150$ ). Respondents with high and low self-esteem appreciated this value to a similar degree.

\section{A Sense of Accomplishment vs. Self-Esteem}

The hypothesis that low self-esteem is related to higher appreciation of the value $A$ Sense of Accomplishment was not confirmed in this study $(t=0.41, p=0.677)$. It turns out that people with low and those with high selfesteem do not differ in how important A Sense of Accomplishment is to them.

\section{Social Recognition and Self-Esteem}

The authors looked for statistically significant differences between low self-esteem and a high ranking of the value Social Recognition. There were no differences between individuals with high self-esteem and those with low self-esteem when it comes to the level of importance attributed to social recognition $(t=0.832, p=0.407)$.

\section{Conformity Values vs. Self-Esteem}

In contrast to the other values, some statistically significant differences $(t=-3.203, p=0.002)$ were found between participant groups which showed that the level of self-esteem correlated with the degree of importance attached to Conformity Values (Cleanliness, Self-Control, Politeness and Obedience). Persons with low self-esteem appreciated Conformity values more than did individuals with high self-esteem.

\section{Value groups vs. gender}

Also, during this study the authors performed a statistical analysis of gender differences in terms of preference for particular value groups. The results of the analysis are shown in the table below.

Men tended to rate Hedonistic values more than women did $(t=-5.43, p<0.001)$. A similar tendency was found in case of Intellectual values $(t=-6.230, p$ $<0.001$ ). These two groups of values were clearly more important to men than to women. On the other hand, women, compared to men, attached greater importance to Relational values $(t=2.152, p=0.032)$. In case of Subjective values, men and women showed equal appreciation $(t=1.45, p=0.147)$. 
The last group of values compared by gender, i.e. Aesthetic values, were also rated equally important by men and women. The result of the independent samples t-test was not statistically significant $(t=1.45, p=0.148)$.

\section{Additional observations}

Aside from the hypotheses tested in this study, we also conducted exploratory analyses so as to determine any differences in valuation between participants with different levels of self-esteem. The analyses were performed using an independent samples t-test (to compare means). The following values were looked at: Self-Control, Courage, Pleasure, and A Comfortable Life.

The analysis showed that values such as $A$ Comfortable Life $(t=-2.57, p=0.011)$, Pleasure $(t=-2.16, p=0.032)$ and Self-Control $(t=-2.68, p=0.008)$ were more highly appreciated by people with lower self-esteem. Persons with high selfesteem, on the other hand, attached greater importance to Courage ( $t=2.736, p=0.007)$ (Table 5).

\section{Discussion}

The authors of the present study formed hypotheses suggesting there are differences in preferences for individual values between people with high versus low self-esteem.

The first hypothesis suggesting that people with higher self-esteem appreciated politeness more than people with low self-esteem did, was not confirmed. In our study, people with low self-esteem considered this value more important than participants with high self-esteem. On average, the former group ranked politeness half a position higher than the latter (individuals with a higher self-esteem). The findings of the authors of this study stand in contrast to Bilsky and Schwartz's [11] and Kwan, Kuang and Huia's [12] findings, yet it is not an isolated case. A negative correlation between self-esteem and politeness was also demonstrated in a study by Lönnqvist and his research team [28]. Perhaps, people with a lower self-esteem value politeness more because they interpret it as a sign of approval from others.

The second hypothesis, which postulated that people with high self-esteem attached greater importance to selfrespect was not confirmed, either. There were no differences in the preference for this value between people with low and high self-esteem. There are empirical data which confirm the finding that self-respect is a value appreciated also by people with low self-esteem. In a study by Wawrzyniak [29] conducted on a group of Adult Children of Alcoholics and found that self-respect was one of the most cherished values. Individuals with a higher selfesteem have a greater tendency to demand respect for their rights and a greater proclivity to "take matters in their own hands". [16] On the other hand, in people with low self-esteem, the preference for self-respect may arise from their unsatisfied needs and difficulties in meeting this value in everyday life.

Similarly to Hypotheses 1 and 2, there was no confirmation for the hypotheses which postulated that people with low self-esteem were more appreciative of a sense of accomplishment and social recognition (Hypotheses 3 and 4). There were no differences in the preferences for those values between respondents with a low and high self-esteem. Empirical studies confirm that achieving success boosts one's self-esteem and a sense of happiness, while failure contributes to a low self-assessment [30]. People with high selfesteem are ready to engage in a variety of activities, even risky ones and they are also more consistent in pursuing their goals [31]. In a study by Romanowska-Tołłoczko et al., [32] people practicing swimming were characterized by both an above-average achievement motivation and a higher selfesteem compared to the rest of the population. A sense of accomplishment and social recognition can, therefore, also be important to and cherished by this group of people, as it is associated with taking action in order to achieve further successes, which, in turn, reinforce high selfevaluation. It is possible that Social Recognition fulfils different (though equally important) functions in both the low self-esteem and the high self-esteem groups. In the case of low self-esteem, this value may guide individuals to take actions allowing them to better adapt to a group in order to avoid rejection; in people with high self-esteem, on the other hand, appreciation of social recognition might be linked to the focus on boosting their prestige in the group and strengthening their position. This is due to the fact that there is a positive correlation between selfesteem and the need for social approval. [33] Moreover, people with low self-esteem are more sensitive to social rejection [23]; however, this does not necessarily imply they attribute a higher status to social recognition. Apparently, the opposite is the case here - individuals considering their social position as low may tend to undermine the value of social recognition, in order to prevent the negative emotions from arising as a response to their being unaccepted by the group. Individuals with low self-esteem seek to confirm their negative beliefs about themselves and interact with people who think of them that way, while staying away from relationships in which they are evaluated positively [34]. People with low self-esteem are not certain whether they have positive or negative qualities. When dealing with a task, they do their utmost to avoid a failure. The tendency to protect the Ego and an uncertain self-image lead to a lack of faith in achieving success [22] While people with low self-esteem focus on avoiding failure, people characterized by a high level of self-esteem set themselves ambitious goals associated with achievement. They exhibit an active attitude toward challenges [23]. Moreover, they are more likely to take 
risks to prove that they deserve recognition. People with low self-esteem behave in an opposite way - they are reluctant to take risks. They prefer safe situations, even if it means giving up the possibility of achieving success. In threatening situations, they are more prone to harm and fare much worse when it comes to coping with difficulties or stress.

The hypothesis that people with low self-esteem appreciate Conformity values more than do people with high selfesteem (Hypothesis 5) was confirmed by statistical data. This indicates that Restrictive Conformity values are particularly important to people with low self-esteem. Values such as SelfControl, Politeness, Obedience, and Cleanliness are associated with the desire to maintain or obtain a position in a particular social group. They are instrumental values, which help a person to achieve goals related to membership in a group. These values then have a goal, an objective and are guided by a specific motivation [24]. People with low self-esteem are characterized by conformity [25], which allows them to earn recognition from a social group and soothes the sense of lower self-worth. A high appreciation for Conformity values is so important [24], because it brings personal benefits.

It was also shown that women appreciate Relational values higher compared to men. A number of studies on gender differences in interpersonal relationships demonstrate that women are more focused on relationships with other people [35]. Moreover, women are more likely than men to take actions based on long-term, regular relationships with others [36]. Taking into account socio-cultural factors - both sexes are assigned traditional roles in society, which entail specific upbringing patterns and specific experiences associated with them following from slightly different expectations toward men vs. women [37]. Women attach more importance to anything that is related to personal life and interpersonal relations, as well as interpersonal communication [38]. Overall, it is more important for women than for men to maintain good relationships with friends or foster close relationships with others. A study by Petrides and Furnham [39] has shown that women appreciate social skills more than men do - in fact, the latter are much more focused on certain tasks and actions [40]. Surveys conducted among students show that women are much more likely than men to combat stress through seeking contact with others. This is due to their need for social support and the orientation toward relationships that are the source of support for women [41]. On the other hand, men tend to assign a higher rank to intellectual values than women do. They are, as it has been shown in various research studies [36,37], focused primarily on tasks and objectives. This is probably largely related to the specifics of gender socialization [42]. Men are mainly focused on tasks they have to fulfill. They have needs related to both emotional and cognitive control of the situation and effective coping with it [43]. This means, when compared to women, they show more preference for intellectual values, which are involved in the process of performing a task and achieving a goal [44]. Men rank hedonistic values much higher than women. This is probably associated with a lifestyle that is so popular with young people, members of the study group. These findings can also be explained in terms of men being less concentrated on values related to relationships and family. They assign more importance to living an enjoyable life, particularly when they do not have to fulfill family-related duties (being a father or husband) or professional roles. There were also other studies showing that young men are more likely to rate hedonistic values high $[39,45]$.

The present exploratory study revealed that people with low self-esteem assign higher importance to such values as Comfortable Life and Pleasure and the instrumental value Self-Control. People with low self-esteem are more likely to experience negative emotions, disappointment and a sense of unhappiness [46]. It is possible that for this reason they show more appreciation of hedonistic values, which may be related to their need for experiencing pleasure and positive sensations. In addition, this very study showed that people with high self-esteem assign a higher rank to Courage. Several studies [23,33] have demonstrated that there is a positive correlation between high self-esteem and willingness to take various actions, including risky ones. It might be expected then that people with high self-esteem will appreciate courage as a value that plays a role in taking action and achieving success. This may also be related to the greater autonomy of these people, which is one of the factors affecting their mental well-being [47]. Individuals with higher self-esteem tend to have a greater sense of satisfaction with life [13]. Another factor which promotes courage, allowing a person to be a sail and rudder, an autonomous individual is low social anxiety [48], which often characterizes people with high self-esteem [20]. The correlation between high selfesteem and preference for Courage may also be associated with the self-promoting style of action of those people.

It is essential to point out the weaknesses of the present study. The study group comprised of university students only, so the results expand the knowledge about value preferences of students with high and low selfesteem. There are very limited possibilities of ascribing the obtained results to other social groups. The differences in value preferences between men and women concerned individuals who were probably unmarried. Looking at the very same individuals through the lens of longitudinal studies might be very interesting. Factors like changes in the value preferences in men and women before and after marriage, as well as during their university years and after they have entered the job market and started their first job should be paid attention to. It needs 
emphasizing that the present study focuses mostly on people with either very high or very low self-esteem. Thus far, little is known about the functioning of people with moderate levels of self-esteem [14], so it is important to describe value preferences also in this group of people.

The SES questionnaire is a reliable and valid instrument with respect to the theory on which it is based, [46] however, it is only used to measure the level of global selfesteem. As such it does not offer the possibility of analyzing the various components of self-esteem which have been identified by O'Brien and Epstein [49] and which can be measured by the Multidimensional Self-Esteem Inventory (MSEI). The SES questionnaire is used to measure explicit (conscious) self-esteem (as shown by the direct statements used such as "I like myself"). According to Greenwald and Banaji [49], there is also implicit selfesteem, defined as "the introspectively unidentified [...] effect of the self-attitude on evaluation of self-associated and self-dissociated objects". An interesting prospect for further research is therefore to analyse the relationships between value preference and self-esteem as a consciously unidentified attitude towards one's own Ego.

The results obtained in this study broaden the knowledge about both gender differences in value preferences, as well as differences between students with low and high (explicit, global) self-esteem [50]. These findings may be used for therapeutic purposes, when working with peoplesuffering from low self-esteem. They might help them become aware of their own needs and the related aspirations (for example, conformity can serve the goal of gaining social approval, which is why it is so important to this group of people).

\section{References:}

1. Oleś P. K. Wartościowanie a osobowość. Psychologiczne badania empiryczne. Lublin; Wydawnictwo Katolickiego Uniwersytetu Lubelskiego: 1989.

2. Sillamy N. Słownik psychologii. Katowice; Wydawnictwo Książnica: 1995.

3. Rokeach M. The Nature of Human Values. New York; Free Press: 1973.

4. Reber A.S., Reber E.S. Słownik psychologii. Warszawa; Wydawnictwo Naukowe Scholar: 2000.

5. Brzozowski P. Skala Wartości (SW). Polska adaptacja Value Survey M. Rokeacha. Warszawa; Pracownia Testów PTP: 1989.

6. Brzozowski P. Skala Wartości Schelerowskich SWS. Podręcznik. Warszawa; Pracownia Testów Psychologicznych PTP: 1995.

7. Lipiec J. Świat wartości. Wprowadzenie do aksjologii. Kraków; Fall: 2001.

8. Basiaga-Pasternak J. Hierarchia wartości sportowców - zawodników piłki nożnej. Ann Univ Mariae Curie Sklodowska, 2005; 60(1): 63-69.

9. Feather N.T. Human Values, Global Self-Esteem, and Belief In a Just World. J Per, 1991; 59(1): 83-107.

10. Maslow A. Motivation and personality. New York; Harper \& Row: 1954.

11. Bilsky W., Schwartz S. Values and personality. Eu J Per, 1994; 8(3): 163-181.
12. Kwan V. Kuang, L. Hui N. Identifying the Sources of Self-esteem: The Mixed Medley of Benevolence, Merit, and Bia. Self and Identity, 2009; 8(2): 176-195.

13. Reykowski J. Osobowość jako centralny system regulacji i integracji czynności człowieka. W: Tomaszewski T. red., Psychologia. Warszawa; PWN: 1975, s. 762-825

14. Oleś P. K. Wprowadzenie do psychologii osobowości. Warszawa; Wydawnictwo Naukowe Scholar: 2011.

15. Zalewska-Puchała J., Ogórek-Tęcza B. System wartości pielęgniarek pediatrycznych. Ann Univ Mariae Curie Sklodowska, 2005; 60(6): 393-399.

16. Piotrowski J., Żemojtel-Piotrowska, M. Kwestionariusz roszczeniowości. Roczniki Psychologiczne, 2009; 12(2): 151-177.

17. Kozak, D. Pracoholizm a neurotyzm - osobowościowe uwarunkowania uzależnienia od pracy. E- mentor, 2005; 5(12): 58-64.

18. Krok D. System wartości a poznawcze i społeczne wymiary religijności. Roczniki Psychologiczne, 2010; 13(2): 161-182.

19. Lachowicz-Tabaczek K. Pomyśl może, że więcej coś znaczysz... Charaktery, 2011; 168, 16-25.

20. Leary M., Kowalski R. M. Lęk społeczny. Gdańsk; GWP: 2001.

21. Pervin L. A. Psychologia osobowości. Gdańsk; GWP: 2002.

22. Dzwonkowska I., Lachowicz-Tabaczek K., Łaguna M. Samoocena i jej pomiar. Podręcznik. Warszawa; Pracownia Testów Psychologicznych PTP: 2008.

23. Wojciszke B. Człowiek wśród ludzi. Zarys psychologii społecznej. Warszawa; Scholar: 2004.

24. Schwartz S.H., Bilsky W. Toward a universal psychological structure of human values. J Pers Soc Psychol, 1987; 53(3): 550-562.

25. Doliński D. Niepewność samooceny a konformizm. Przegląd Psychologiczny, 1993; 36(1): 27-37.

26. Brzozowski P. Polska wersja testu wartości Rokeacha i jej teoretyczne podstawy. Przegląd Psychologiczny, 1986; 2, 527-539.

27. Brzozowski P. Relacje między wartościami w świetle badań dyferencjałem semantycznym. W: Puzynina J., Bartmiński J. red., Język a Kultura (tom 2). Wrocław; Wydawnictwo Uniwersytetu Warszawskiego: 1991, s. 355-383.

28. Lönnqvist J. ,Verkasalo M., Helkama K., Andreyeva G., Bezmenova I., Rattazzi A., Niit T., Stetsenko A. Self-esteem and values. Pfugers Arch, 2009; 39(1): 40-51.

29. Wawrzyniak I. System wartości ze szczególnym uwzględnieniem rangi pracy wśród dorosłych dzieci alkoholików. Acta Universitatis Lodziensis. Folia psychologica, 2001; 5, 127-136.

30. Baumeister R.F., Campbell J.D., Krueger J.I., Vohs K. D. Does high self-esteem cause better performance, interpersonal success, happiness, or healthier lifestyles? Psychological Science in the Public Interest, 2003; 4, 1-44.

31. Baumeister R.F., Smart L., Boden, J.M. Relation of threatened egotism to violence and aggression: The dark side of self-esteem. Psychol Rev, 1996; 103, 5-33.

32. Romanowska-Tołłoczko A., Marks M., Tomczak R. Motywacja osiągnięć i samoocena studentów uprawiających pływanie w sekcjach sportowych AZS działających przy wrocławskich uczelniach. Pedagogics, Psychology, Medical-Biological Problems of Physical Training and Sports, 2007; 10, 152-156.

33. Kenrick D.T., Cialdini R.B., Neuberg L.S. Psychologia społeczna. Gdańsk; GWP: 2002.

34. Wojciszke B. Psychologia społeczna. Warszawa; Scholar: 2011.

35. Argyle M. Psychologia szczęścia. Wrocław; Wydawnictwo Astrum: 2001.

36. Aronson E., Wilson T.D., Akert R. M. Psychologia społeczna: serce i umysł. Poznań; Wydawnictwo Zysk i S-ka: 1997.

37. Knopp K.A. Czy kobiety naprawdę są bardziej inteligentne emocjonalnie niż mężczyźni? 0 różnicach międzypłciowych $\mathrm{w}$ 
zakresie zdolności emocjonalnych. Kwartalnik Naukowy Towarzystwa Uniwersyteckiego Fides et Ratio, 2012; 4(12): 95-112.

38. Siwy-Hudowska A., Kieszkowska-Grudny A. Osobowość makiaweliczna i jej czynniki w porównaniach międzypłciowych: znaczenie inteligencji emocjonalnej i lęku. Psychologia Społeczna, 2010; 1(13): 27-41.

39. Knopp K.A. Inteligencja emocjonalna oraz możliwości jej rozwijania u dzieci i młodzieży. Warszawa; Wydawnictwo Kardynała Stefana Wyszyńskiego: 2010

40. Moir A., Jessel D. Płeć mózgu: o prawdziwej różnicy między mężczyzną a kobietą. Warszawa; Państwowy Instytut Wydawniczy: 2000.

41. Bishop G. Psychologia zdrowia. Wrocław; Wyd. Astrum: 2007.

42. Saarni C. Kompetencja emocjonalna i samoregulacja w dzieciństwie. W: Salovey P., Sluyter D.J. red., Rozwój emocjonalny a inteligencja emocjonalna: problemy edukacyjne. Poznań; Dom Wydawniczy Rebis: 1999, s. 75-125.

43. Dudek A. Style radzenia sobie ze stresem i inteligencja emocjonalna u studentów kierunków społecznych i politechnicznych. Niepublikowana praca magisterska. Lublin; Instytut Psychologii, KUL: 2013.

44. Maruszewski T., Ścigała E. Emocje, aleksytymia, poznanie. Poznań; Wydawnictwo Fundacji Humaniora: 1998.

45. Siudem A. Preferowane wartości a podejmowanie decyzji o zawarciu związku małżeńskiego przez osoby w wieku wczesnej dorosłości. W: Збірник матеріалів науково-практичної конференції «Гендерна освіта-ресурс розвитку паритетної демократії». Київ; Міністерство Освіти I Науки, Молоді Та Спорту України, Національна Академія Педагогічних Наук України, Інститут Психології Імені Г.С. Костюка Напн України: 2011, s. 102-111.
46. Łaguna M., Lachowicz-Tabaczek K., Dzwonkowska I. Skala samooceny SES Morrisa Rosenberga - polska adaptacja metody. Psychologia społeczna, 2007; 2(4): 164-176.

47. Ryff C.D. Happiness is everything, or is it? Explorations on the meaning of psychological well-being. J Pers Soc Psychol, 1989; 57(6): 1069-1081.

48. Dziwota K. Samoświadomość a dobrostan psychiczny u osób z lękiem społecznym. Niepublikowana praca magisterska. Lublin; Instytut Psychologii, KUL: 2013.

49. Domurat M. O różnych miarach samooceny. W: Paluchowski W.J., Bujacz A., Haładziński P., Kaczmarek L. red., Nowoczesne metody badawcze w psychologii., Poznań; Wydawnictwo Naukowe Wydziału Nauk Społecznych UAM: 2012, s. 223-233.

50. Woydyło K. Charakterystyka problemu uzależnienia od pracy w świetle dotychczasowych badań. Nowiny Psychologiczne, 2003; 3, 33-50.

\section{Correspondence address}

Kamila Dziwota

Katolicki Uniwersytet Lubelski Jana Pawła II

Aleje Racławickie 14, 20-950 Lublin

Email: kamidziwota@gmail.com

Tel: 513-306-125

Otrzymano; 10.03.2016

Zrecenzowano 30.032016

Otrzymano po poprawie 30.05.2016

Przyjęto do druku 08.06.2016 